\title{
Energy Optimization of Buildings through Sustainable Materials
}

\author{
V. Baby Shalini, K. Nagasujatha
}

\begin{abstract}
Worldwide, buildings are accountable for a huge share of electrical energy, materials and water consumption. Buildings and construction causes for $39 \%$ of energy related $\mathrm{CO}_{2}$ emissions as per world green building council. Aim of Green building is to reduce emissions and also reduce energy consumption by using energy efficient appliances. green building design features have higher initial costs, but the payback period for the incremental investment is less. eco-friendly buildings can grant indirect cost-effective benefits to both the building owner and society in addition to direct cost savings. In this paper design of green building and analysis has been done with BE opt software by considering different parameters.
\end{abstract}

Keywords: BE opt simulation, Conventional Vs Green Building,Co2 Emissions,, HVAC.

\section{INTRODUCTION}

The technology of Green building plays a vital role in the reduction of electrical energy consumption and $\mathrm{CO}_{2}$ emissions .A building which reduces negative impacts and can create positive impacts with its design and construction on environment is called green building. Our quality of life also improved by green buildings. There are many features which makes a building green are listed below.

1.utilization of electrical energy ,water resources efficiently. 2.installing the renewable resources like solar, wind etc.

3.Utilization of materials which are non-toxic, sustainable and ethical

4.air quality of indoor environment should be good

5.waste reduction by enabling of re-use and recycling.

6.upgrade the building to maintain a good thermal comfort inside .

8.Utilization of energy efficient appliances and materials which consume less energy.

Sustainable buildings typically have lower annual costs for energy, water, maintenance/repair, other operating expenses. With proper orientation of building to receive more day light, walls with lower $U$ values, water-harvesting methods , roof insulation, and more use of efficient appliances can reduce energy needs.
Revised Manuscript Received on February 05, 2020.

* Correspondence Author

Baby Shalini*, Assistant Professor, Department of Electrical and Electronics Engineering, JNTUHCE Jagtial, Telangana, India.

E-mail:shalini815@yahoo.com

K. Nagasujatha, Professor, Department of Electrical and Electronics Engineering, JNTUH, Telangana, India. E-mail:knsjntuh@gmail.com.

(C) The Authors. Published by Blue Eyes Intelligence Engineering and Sciences Publication (BEIESP). This is an open access article under the CC BY-NC-ND license (http://creativecommons.org/licenses/by-nc-nd/4.0/)
In this paper HVAC-heating, ventilation and air-conditioning ,lighting is major constraint for power consumption in a building. A properly designed HVAC, using energy efficient lighting equipment reduce power consumption in buildings drastically.

\section{BE OPT SOFTWARE}

BEopt simulation is used to design a cost-optimal building towards a zero net energy (ZNE) building. In BEopt, it has three screens. One is geometry screen, second is options screen and third is output window. In this paper BEopt 2.8.0.0 is used to design and analyse the green building. The important parameters considered for green building design are

1.neighbours for building

2.use of PV

3.electrical appliances

4.wall insulating material

5.ceiling material

\section{SIMULATION RESULTS OF CONVENTIONAL BUILDING}

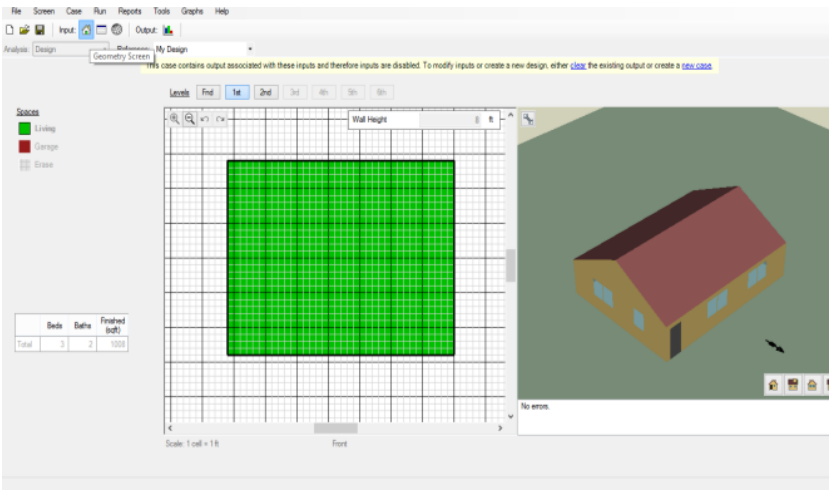

Fig.1.Design Of Conventional Building

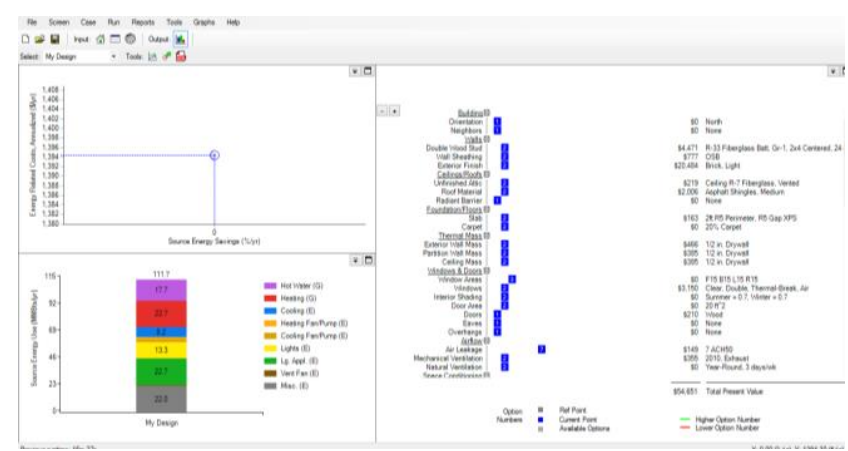

Fig.2.Source Energy Use, Annualized Energy Related Costs for Conventional Building 


\section{Energy Optimization of Buildings through Sustainable Materials}

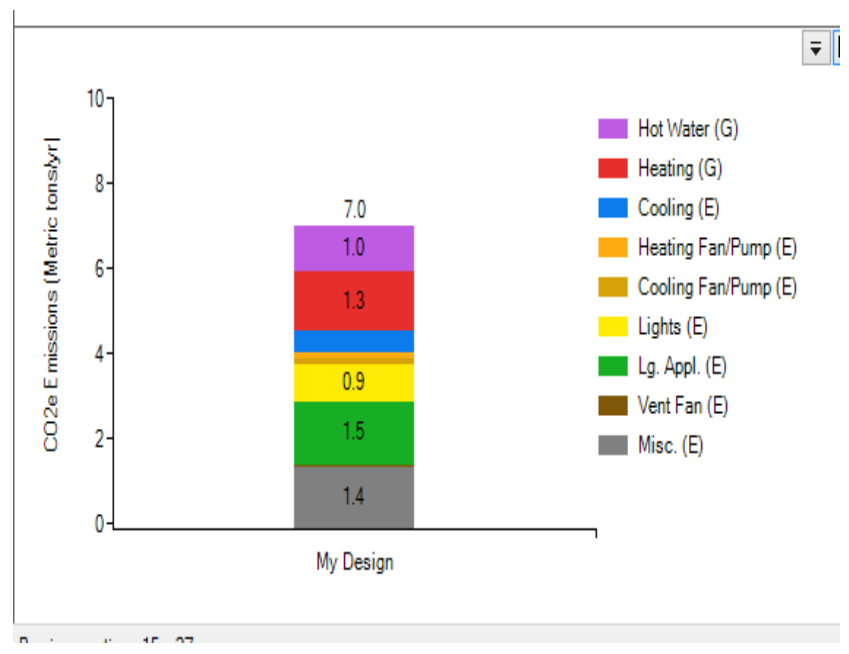

Fig.3. Co2 Emissions Due To Conventional Building

\section{SIMULATION RESULTS OF GREEN BUILDING}

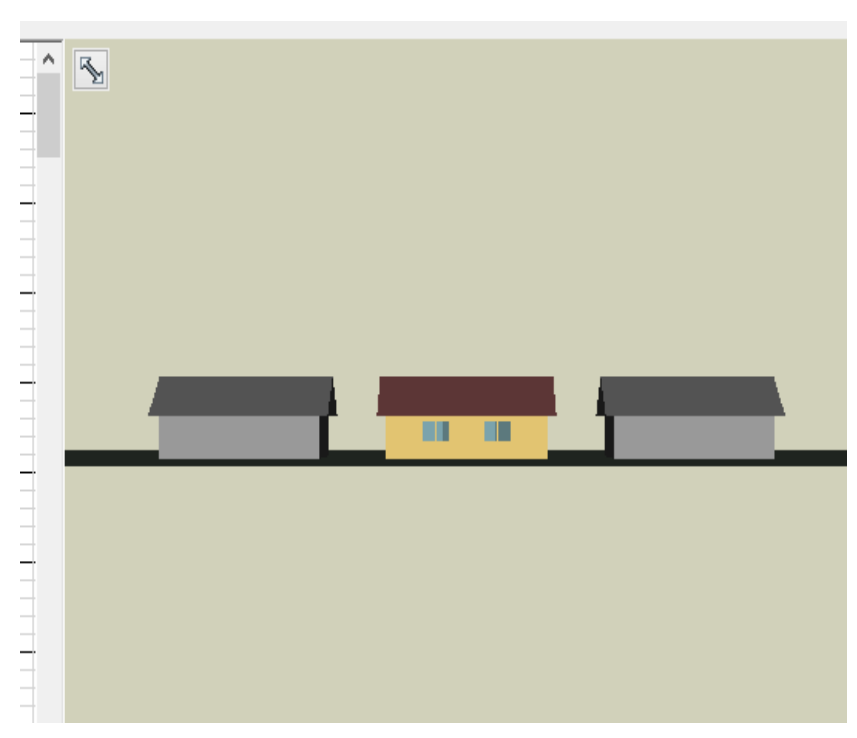

Fig4.Proposed design of Green Building

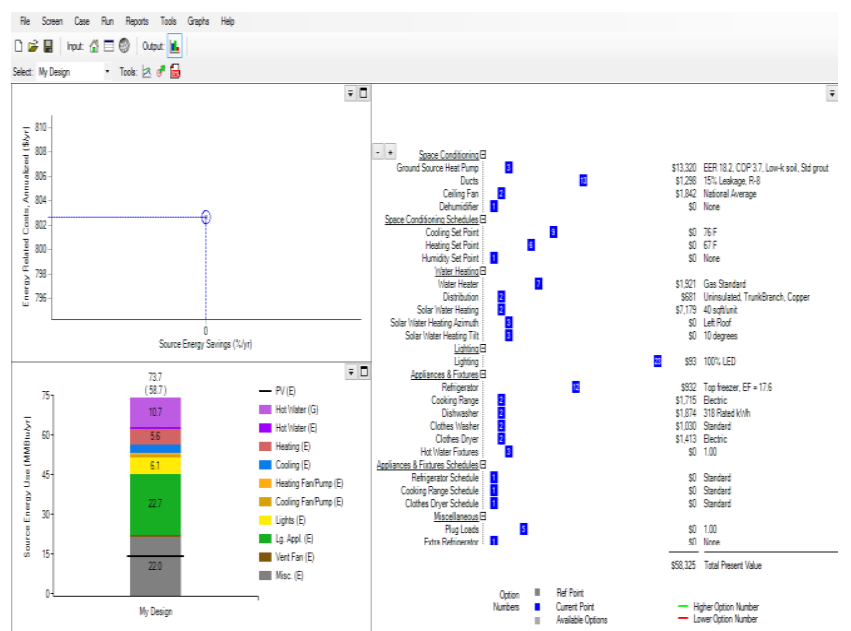

Fig.5.Source Energy Use, Annualized Energy Related Costs For Green Building

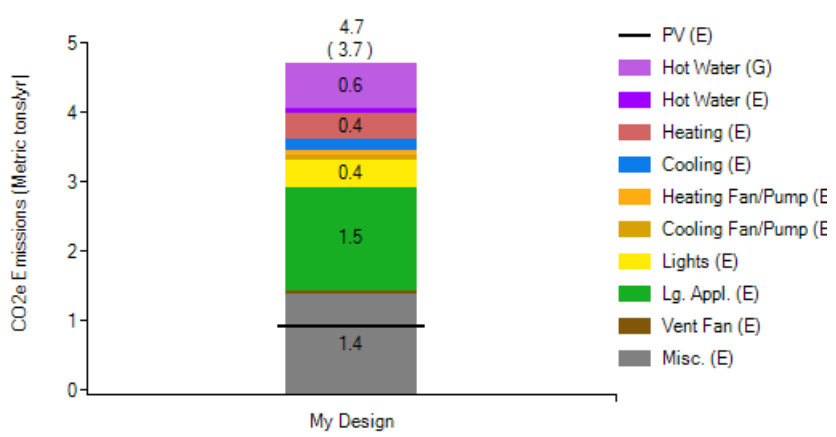

Fig.6. Co2 Emissions Due To Green Building

\section{RESULT ANALYSIS}

For simulation a building of 1008 sq.ft.is designed .

Table.1.Comparision Of Conventional And Green Building Simulation

\begin{tabular}{|l|l|l|l|l|}
\hline Building & $\begin{array}{l}\text { Cost of } \\
\text { the } \\
\text { building( } \\
\$ \text { type }\end{array}$ & $\begin{array}{l}\text { Source } \\
\text { energy } \\
\text { use(MMbtu } \\
\text { /yr) }\end{array}$ & $\begin{array}{l}\text { Energy } \\
\text { related cost } \\
\text { annualzed( } \\
\$ \text { /yr) }\end{array}$ & $\begin{array}{l}\mathrm{CO}_{2} \text { emissio } \\
\text { ns(metric } \\
\text { tonns/yr) }\end{array}$ \\
\hline $\begin{array}{l}\text { Conventi } \\
\text { onal } \\
\text { building }\end{array}$ & 54651 & 111.7 & 1394 & 7.0 \\
\hline $\begin{array}{l}\text { Green } \\
\text { building }\end{array}$ & 58325 & 73.7 & 803 & 4.7 \\
\hline
\end{tabular}

From the simulation results of conventional and green building we can conclude that:

1.Source energy use is reduced from 111.7 to $73.7 \mathrm{MMbtu} / \mathrm{yr}$. For example by using $100 \%$ incandescent lamps in conventional building causes $13.3 \%$ of total energy use and using $100 \%$ LED in green building causes $6.1 \%$ of total energy use.

2.Annualized energy related cost is reduced from 1394 to 803 $\$ / \mathrm{yr}$

3. $\mathrm{CO}_{2}$ emissions reduced from 7 to 4.7 metric tonns/yr 4.Cost of building is increased from $54651 \$$ to $58325 \$$

\section{CONCLUSION}

From simulation results difference between green building and conventional cost is $58325 \$-54651 \$=3674 \$=R s$. 260854 Annual energy related cost difference is 1394-803=591\$=Rs.41,961.

Payback period for the proposed design is 260854/41961=6.2 yrs. Source energy usage i reduced by $65 \%$ with construction of green building. In order to save energy and reduce $\mathrm{CO}_{2}$ emissions green building technology is very useful.

\section{REFERENCES}

1. G.R.K.D. Satya Prasad "HVAC system performance and operational strategies in Green buildings - A Simulation approach" International Research journal of Engineering and Technology" Vol. 3, Issue 2, March - 2016

2. Torcellini, Paul A., and Drury B. Crawley. "Understanding zero-energy buildings." ASHRAE journal 48.9 (2006): 62-69.

3. Attia, Shady, et al. "Simulation-based decision support tool for early stages of zero-energy building design." Energy and buildings 49 (2012): 2-15. 
4. chandragiri Radha charan,K.Nagasujatha"A practical case study of PVSOL system "at National Energy conservation Week-2018,organized by Energy conservation mission, The institute of engineers in association of Telangana state Renewable Energy Development Corporation Ltd.,Hyderabad on 14th December 2018.

\section{AUTHORS PROFILE}

Baby Shalini, Assistant Professor, Department of Electrical and Electronics Engineering,JNTUHCE Jagtial, Telangana, India,shalini815@yahoo.com

K. Nagasujatha, Professor, Department of Electrical and Electronics Engineering,JNTUH, Telangana, India,knsjntuh@gmail.com. 